UDK 78.01 Banfi

\author{
Luisa Antoni
}

Noghere 27/b

I-34147 Milje pri Trstu

\title{
Antonio Banfi in njegova smer v sodobni glasbeni estetiki
}

\section{Antonio Banfi and His School of Thinking in Contemporary Musical Aesthetics}

Ključne besede: fenomenologija, italijanska muzikologija, estetika glasbe, Antonio Banfi

IZVLEČEK

Italijanski filozof Antonio Banfi (1886-1957) se je v prvi polovici 20. stoletja ukvarjal z raziskovanjem estetike in je $\mathrm{v} 20$. in 30. letih na milanski Univerzi oblikoval svojo šolo razmišljanja. Banfi je vezna točka med evropsko tradicijo ter vplivi Kanta in Hegla po eni strani, po drugi pa strelovod za nove, inovativne misli, ki so preplavljale Evropo (Simmel, Dessoir, Valéry in predvsem Husserl). V članku avtorica nakazuje glavne smernice njegove estetike in zasleduje, kako so te smernice vplivale na oblikovanje italijanske glasbene estetike.
Keywords: phenomenology, Italian musicology, aesthetics of music, Antonio Banfi

Abstract

The Italian philosopher Antonio Banfi (18861956) was engaged in aesthetic research in the first half of the 20th century, and in the twenties and thirties founded his own school of thinking at the Milan University. On one hand, Banfi represents a link between European tradition and the influences of Kant and Hegel, and on the other, a "lightning conductor" for new, innovative thoughts that were spreading throughout Europe (Simmel, Dessoir, Valéry, and above all Husserl). The paper gives a survey of guidelines of Banfi's aesthetics, tracing their influence upon the formation of Italian musical aesthetics.

\section{"Hostinato rigore $«^{1}$}

Navadno je raziskovanje filozofskih prvin v glasbi in mislih glasbenikov nekaj nenavadnega $\mathrm{v}$ filozofiji in celo $\mathrm{v}$ sami estetiki: poglabljanje teh pojmov je namreč nekje sredi poti med samim filozofskim razglabljanjem in glasbenim svetom, tako da bi lahko rekli tej stroki, da ni ne tič ne miš, ampak čisto poseben netopir. Verjetno se marsikdo, predvsem iz vrst glasbenikov in muzikologov sprašuje, čemu iskati tega nočnega sramežljivo izogibajočega se netopirja, torej estetsko-filozofski okvir glasbi. Moj odgovor

Avtor tega mota je Leonardo, Banfi pa je izpisal te besede na začetku zveščiča, v katerem si je zapisoval svoja razmišljanja $\mathrm{v}$ aprilu 1920. 
je preprost ali pa tudi ne: človek, umetnik živi v času in prostoru, diha kulturno ozračje okrog sebe in zato obsvetje ne more ne vplivati na njegovo delo: če razumemo oz. bolje spoznamo okvire, v katerih se giblje, nam bodo njegove umetnine in njegova umetniška pot bolj razumljivi in jih bomo po eni strani lahko bolje razlagali in tolmačili tistim, ki se s tem ne ukvarjajo profesionalno in želijo priti do manj površnega razumevanja in podoživljanja umetnosti; po drugi strani pa bomo sami lahko prišli do globljega in popolnejšega razumevanja tistega čuda, ki se vsakič pokaže v umetnosti in se sproti - kot Sfinga - izmika vsakršnemu poskusu definiranja. ${ }^{2}$ Ker je moje glasbeno raziskovanje od nekdaj razpeto med filozofijo, natančneje fenomenologijo, in muzikologijo, se mi je poglabljanje filozofije in šole danes manj znanega italijanskega filozofa Antonia Banfija ponudilo tudi kot pravi preizkusni kamen pri iskanju odgovora na vprašanje, ali je glasbena estetika upravičeno del filozofije, saj se celo sama estetika zdi kot neke vrste stranska veja glavne filozofske krošnje. Kar zadeva čas sodi Banfijevo raziskovanje v zahodni kulturnozgodovinski okvir, ki je zelo razgiban. »V prvih desetletjih 20. stoletja se je med starimi modeli, predvsem idealistične narave, v metafizičnih in abstraktno sistemskih teoretiziranjih, pojavil pojem znanost ali splošna teorija umetnosti. ॥ $^{3}$ Mikel Dufrenne nas še opozarja, da je »v več evropskih državah, kot tudi v ZDA, od leta 1930 dalje estetika videla svoj veliki razvoj ne samo v najuglednejših mojstrih, temveč tudi v odmevnem mrgolenju raziskav in šol«, prej, v prejšnjih desetletjih pa je »tisti, ki se je ukvarjal z estetiko ali zgodovinar, bil veliko bolj doma v renesansi kot v fauvizmu, kubizmu, glasbi Debussyja, Stravinskega ali Schönberga« ${ }^{4}$ Če izberemo primer iz prostora in časa, s katerim se ukvarja pričujoči članek, lahko npr. ob prebiranju spisa o kompoziciji, ki ga je objavil Goffredo Petrassi, ugotovimo, da je ena pomembnih smernic takratne glasbe vez med tehniko in estetiko in obenem potreba po posodobitvi načinov, kako priti do umetnosti nasploh. ${ }^{5}$

$\mathrm{V}$ italijanski estetiki je Antonio Banfi vezna točka med evropsko tradicijo ter vplivi Kanta in Hegla po eni strani, po drugi pa strelovod za nove, takrat inovativne misli, ki so prepljavljale Evropo (Simmel, Dessoir, Valéry in predvsem Husserl). ${ }^{6}$ Rodil se je v mestecu Vimercate blizu Milana 30. septembra 1886. Jeseni 1909. je doktoriral, njegov prvi zapis o estetiki sega v leto 1910, prvi zaokrožen spis pa v leto 1920. Po doktoratu se je s štipendijo odpravljal v Berlin; tam je živel od 28. aprila 1910 do marca leta $1911 .^{7}$ V pismu prijatelju Giovanniju Marii Bertinu je svoje izkušnje opisal takole:

Italijanska glasbena estetika je na tej poti storila kak korak več kot slovenska: v preteklosti nem je Enrico Fubini ponudil svojo zgodovino glasbene estetike v dveh knjigah, nedvomno najvidnejši in najpomembnejši dosežek zadnjih let pa je zgodovina, ki jo je objavil Giovanni Guanti. Fubinijeva raziskava sega do 60. let, Guanti pa je pogledal še dlje in jo pravzaprav dopolnil in nadgradil ter nam tako ponudil pomembno oporo. Enrico Fubini, L'estetica musicale dall'antichitá al Settecento in L'estetica musicale dal Settecento a oggi, Torino, Einaudi, 1964; Giovanni Guanti, Estetica musicale: la storia, le fonti, Scandicci, La Nuova Italia, 1999.

M. Dufrenne e D. Formaggio, Trattato di estetica, Mondadori, Milano, 1981; str. 5.

L'année 1913, Klincksieck, Pariz, 1971; str. 25-26.

Mariateresa Muttoni, La formazione del compositore italano nella seconda metá del Novecento, $\mathrm{v}$ La cultura dei musicisti italiani nel Novecento, Guerini, Milano, 2004; str. 77.

Eden pomembnejših Banfijevih učencev Enzo Paci je že leta 1957 trdil, da »je Banfijeva filozofija odločilna pot italijanske misli 20. stoletja do vse sodobne filozofije«. Enzo Paci, La filosofia contemporanea, Milano, 1957; str. 49.

V arhivu Univerze Friedricha Wilhelmsa obstajajo dokumenti, ki pričajo o vpisu Banfija na filozofsko fakulteto. Formaggio piše, da je Banfi v poletnem semestru 1910 sledil Simmlovim predavanjem; v zimskem semestru pa je sledil predavanjem Riehla (Kant), Lassona (Hegel), Sprangerja, Harnacka, Erdmanna, Dessoirja (Einführung in die Aesthetik und allgemeine Kunstwissenschaft), Müsterberga, Willamowitz-Möllendorffa (Politika v Grčiji) in Simmla. Tako kot tudi pozneje s Husserlom se je njegovo občudovanje Simmla spremenilo tudi v osebno prijateljstvo. 
[...] vem, da sem v samem zagovoru [diplomske naloge op.a.] izjavil, da hočem zapustiti zavod, ki me ni mogel ničesar več naučiti: predrzen sem bil, priznam, a iskren. In tudi Italije sem se naveličal: to so bili časi prvih uspehov Croceja in revije La Voce. Oba sta se mi zdela res neznosno in omejeno provincialna. Odšel sem ob prvi priložnosti, tudi iz osebne stiske, in se zatekel v Berlin. Tu sem bil resnično svoboden: niti pomislil nisem, da bi objavil tezo. Spoznati nov svet, novo življenje, nove sloje, živeti pustolovsko, učiti se na pustolovski način. Zatopiti se v glasbo, v Kanta do obisti, z Riehlom, odkriti problem tehnike in sloga v umetnosti z Wölfflinom, dogmatski problem s Harnackom, smisel sveta, ki je zame nov, učiti se antike z Willamowitzem, spet se lotiti Hegla z Lassonom, srečanje $z$ marburškim novokantovstvom in $s$ Cassirerjem in še posebno $s$ Simmlom, z gibljivo in predirljivo bistroumnostjo občutljive in zmeraj pozorne misli. Dessoir mi je predstavil probleme psihologije v novi obliki in mi kazal pot Kunstwissenschafta, Erdmann je razpravljal o logiki, Münster je iz Amerike prinesel duha novega kontinenta. Druge smeri sem spoznal posredno: predvsem šolo filozofije vrednot in potem Fenomenologijo. Po božji volji sem v teh globokih vodah dobro zaplaval. ${ }^{8}$

Niti mesec ni minil po nastanitvi v Berlinu, ko je Banfi že napisal kratek in sintetični razmislek o problemih estetike in tako začel plodna raziskovanja o umetnosti, ki so se uspešno razvila tudi v pravo šolo razmišljanja. Banfijeva učenca Luciano Anceschi in Dino Formaggio sta razdelila estetsko misel Antonia Banfija na tri obdobja, nimata pa enakega stališča glede dolžine teh obdobij. Anceschi meni, da je trajalo prvo obdobje od začetka do leta 1930, drugo od leta 1930 do konca druge svetovne vojne, tretje pa od leta 1945 do Banfijeve smrti. ${ }^{9}$ Formaggio je uredil zbirko Banfijevih spisov, ki je zelo podobna Anceschijevi, in tudi razdelil Banfijevo misel na tri obdobja: prvo pomembno obdobje naj bi segalo od leta 1920 do leta 1926, drugo od let 1931-32 do leta 1947 , tretje pa naj bi se začelo s potovanjem Banfija na Kitajsko. ${ }^{10}$ Glavna razlika med tema časovnima opredelitvama je ta, da Anceschijeva interpretacija upošteva vse dobe Banfijevega razvoja, medtem ko Formaggieva pa samo pomembnejše.

Po koncu prve svetovne vojne se je na italijanskem političnem prizorišču uspešno pojavil fašizem: leta 1921 je dobil 30 izvoljenih deputatov v Zbornici , tj. enem najvišjih italijanskih političnih organov, v letu 1922 se je zgodil umor Matteottija, v letu 1925 je režim onemogočil vsak demokratični izraz, njegovi najpomembnejši še živi nasprotniki pa so bili ali v zaporu ali v tujini. Fašistično nasilje se je vtikalo tudi v kulturo in vsiljevalo avtarkično kulturno avtonomijo. Filozof Benedetto Croce, ki je leta 1910 postal senator in bil od junija 1920 do junija 1921 minister za šolstvo, je najprej mislil, da bo mogoče uokvirjati in usmerjati fašizem znotraj liberalnih inštitucij, je po umoru Matteottija javno izrazil svoje nasprotovanje režimu in glasoval proti vsem zakonom, ki so omejevali svobodo. Croce, s katerim fašizem ni upal fizično obračunati, je postal simbol intelektualnega kljubovanja. Režim je takrat uvedel celo vrsto ukrepov, da bi si zagotovil

\footnotetext{
Pismo Giovanniju Marii Bertin je izšlo v reviji Aut Aut, VII, 1958, 43-44; str. 29-33.

Luciano Anceschi, Formazione dell'estetica di Banfi, v I problemi di un'estetica filosofica, Roma, $1962 ;$ str. XI.

Dino Formaggio, Gli sviluppi dell'estetica di Antonio Banfi, v Filosofia dell'arte, Firenze, 1961; str. 15.
} 
zvestobo državljanov, med temi tudi listino, ki so morali podpisati vsi univerzitetni profesorji. Eden Banfijevih milanskih učencev Remo Cantoni se tako spominja tistih let:

Njemu se moramo zahvaliti, če v tistih težkih in dušečih letih nismo izgubili veselja do intelektualne raziskave in moralne svobode. Banfi je imel zasluge, da je v univerzitetnih učilnicah in pri sebi doma na korzu Magenta zbral okrog sebe zbral boljši del milanske kulture, vse tiste, mlade in manj mlade, ki so se jim intelektualni dogmatizem, zapiranje misli v okvire državnih meja in sektarske ideologije upirali. Milano je bil dolga leta živo središče protifašizma, odprta in univerzalna šola kulture in intelektualna spodbuda je prišla predvsem iz nauka in človeške navzočnosti Antonia Banfija. ${ }^{11}$

Drugi njegov milanski učenec, Luigi Rognoni, pa se še spominja, kako se je Banfi odločil, da bo "sprejel nevarnosti notranjega odpora in se posvetil nalogi pedagoga in vodje mlajših generacij«.

V Milanu smo v letih 1931-32 dobivali Univerzo, prepojeno z idealistično kulturo. Tistim, ki so se usmerjali k raziskovanju problemov umetnosti in so videli v jeziku poetov, slikarjev in glasbenikov možno obrambo in potrditev civilne družbe, še vredne takega imena, se je zdela Crocejeva estetika edino oporišče; toda ni se več ujemala s 'krizo' kulture in ni bila uporabna za to, da bi z njo razlagali, kaj se je dogajalo v preteklosti in se je še dogajalo v umetnosti, kjer je bil umetnik, potem ko se je otresel idealov in shem, v prisotnosti 'življenja' in v 'življenju' odkritosrčno in svobodno kot nikdar prej. Banfijeva beseda se je takrat pojavljala kot nepričakovana razjasnitev, kot vabilo k podiranju shem in norm ter k prepoznavanju umetniške stvarnosti v vsem njenem življenjskem in polnem bogastvu. ${ }^{12}$

Tukaj se torej pokaže eden ključnih trenutkov italijanske estetike: pomen in vpliv Croceja je v tem obdobju italijanske zgodovine deloma vezan tudi na njegova protifašistična politična stališča, v katerih so mlajši rodovi - tako kot smo dejali - videli edino možno obrambo civilnih načel, tudi zato ker je bila Crocejeva beseda res vplivna. Kmalu pa so se zavedeli, da jim Crocejeva estetika ne pomaga pri razumevanju sodobnih umetniških tokov, v katerih se je Evropa prebujala. Leta 1963 je Giovanni Giraldi na začetku svoje obravnave italijanske estetike 20. stoletja trdil, da se italijanska estetika sicer ne začenja pri Croceju, da pa je Croce brez dvoma njena osrednja točka. ${ }^{13}$ Croce

${ }_{11}$ Remo Cantoni, Ricordo di Antonio Banfi, v Antonio Banfi e il pensiero contemporaneo, La Nuova Italia, Firenze, 1969; str. 11.

12 Luigi Rognoni, Il pensiero estetico di Banfi e la vita dell'arte, v reviji Aut aut, 1958, str. 49.

13 Giovanni Giraldi, L'estetica italiana nella prima metá del secolo XX, Naschi-Listri, Pisa, 1963; str. 9. S pomenom Croceja danes so se ukvarjali različni avtorji leta $1998 \mathrm{v}$ reviji Anthropos, med temi tudi Lev Kreft v članku z naslovom Benedetto Croce danes, ki je izšel v reviji Anthropos, 30, št. 4/6 (1998). 
je v italijanski estetiki vseskozi navzoč; z njim in z njegovo estetsko mislijo so operirali in se z njo pomerili (bolj ali manj odkrito) vsi misleci, ki sem jih obravnavala. Ne bom pa se lotila primerjalnih analiz, ker sta Croce in njegova estetika navsezadnje predmet številnih poglobljenih samostojnih raziskav.

Lino Rossi v spisu Di alcune tendenze dell'estetica italiana contemporanea ${ }^{14}$ našteva ob Banfiju še druge pomembne italijanske filozofe, ki ne sodijo v Banfijevo šolo, a so s svojimi deli pripomogli k obnavljanju italijanske estetike (Luigi Pareyson [r. 1918], Rosario Assunto [r. 1915], Nicola Abbagnano [r. 1901], Gillo Dorfles [r. 1910], Guido Morpurgo Tagliabue [r. 1907] in Galvano Della Volpe [r. 1895]). Vendar, če primerjamo letnice njihovega rojstva, lahko ugotovimo, da je bil Banfi najstarejši, zato je seveda oral ledino, na tej poti pa so mu sledili nekaj let pozneje še drugi. To seveda nakazuje na veliko potrebo italijanske estetike po obnavljanju svojih pojmov v nasprotju z idealizmom ali vsaj ne pod njegovim vplivom, torej daleč od Croceja. Fubini v svojem razglabljanju o glasbeni kritiki ugotavlja, da je idealistična metodologija, ki jo je Croce zagovarjal, »najbolj primerno sredstvo za interpretiranje in razumevanje romantične umetnosti«, medtem ko se je Husserlova fenomenologija "pojavila na evropski sceni kot filozofija in estetika bolj primerna za duh avantgard 20. stoletja ${ }^{15}$ Prav v teh besedah se torej pokaže v pravi luči razkorak med obema pojmovanjema umetnosti: Croce izhaja iz paradigme, ki se je že izpela, Banfi pa zastopa novo smer, novo pot, novo paradigmo. Dejansko je Crocejev svet vezan na preteklost, Banfijev pa se odpira sodobnosti. Formaggio je v letih 1985 - 86 v predavanju na milanski Fakulteti za arhitekturo sicer v drugem kontekstu razvil zanimivo idejo, ki je uporabna tudi tu:

Prva točka je ta, da imamo kulturo biti, imenujmo jo tako, lahko za izpeto ali da se končuje. Vedno bolj se uveljavlja kultura nastajanja, kultura dinamičnosti.

$[\ldots]$

Velika paradigma biti je torej zašla in zdaj na obzorju vzhaja nova izredno revolucionarna, če jo primerjamo s prejšnjo, vodilna ideja, tj. ideja o nastajanju, spreminjanju: »ničesar ni in vse se spreminja«. ${ }^{16}$

$\mathrm{V}$ 30. in 40. letih prejšnjega stoletja sta $\mathrm{v}$ bistvu obe paradigmi, ena v crescendu, druga v decrescendu pod trdo roko fašizma, pravzaprav sobivali; šele v povojnem času so nastale spremembe, čeprav je Crocejeva paradigma preživela; "mogočna osebnost Benedetta Croceja je namreč [...] tudi zaradi svojega trdnega nasprotovanja fašizmu postala še pred smrtjo leta 1952 intelektualna legenda «. ${ }^{17}$

S svojim delom v 30. in 40. letih se je Banfi torej šele lotil estetskega območja; njegovo delo pa je obrodilo prave sadove po drugi svetovni vojni, ko je v Italiji zavladala demokracija, ki ni tako grobo posegala v kulturo in je usmerjala kot fašistična diktatura. Sam Banfi opozarja: „Kdor se je formiral v prvih dveh desetletjih [20. op. a.] stoletja, se

\footnotetext{
Lino Rossi, Di alcune tendenze dell'estetica italiana contemporanea, v Studi di estetica, CLUEB, Bologna, 1979. Enrico Fubini, Critica ed estetica musicale in Italia tra '800 e '900, v Rivista musicale italiana, 3, 1999; str. 329.

Dino Formaggio, Appendice: Mutazioni paradigmatiche, v Problemi di estetica, Aesthetica edizioni, Palermo 1991; str. 222. Lev Kreft, Nastanek, konec in začetek estetike, v Mario Perniola, Estetika 20. stoletja, Znanstvenopublicistično središče, Ljubljana 2000; str. 196.
} 
je zavedel radikalne, zapletene, konkretne krize kulture. Zavedati pa se je moral tudi, da je lahko koristno ne to, da bi jo zatajili ali pričakovali idealno rešitev, ampak analiza brez vsakršnih predsodkov «. ${ }^{18}$ Po eni strani je torej Banfi sprejel pojme, ki mu jih je tradicija pustila, tak je bil npr. pojem lepega in lepe umetnosti, ter tako ne nazadnje sprejel tudi nelahko nalogo - primerjanje s Crocejem. ${ }^{19}$ Po drugi strani pa je na novih temeljih razvil pogled na umetnost, po katerem umetnost ni muzejski eksponat, temveč del sodobnega življenja. Banfijeva estetska misel se je razvijala tako, da se je iz začetnih tradicionalnih spon razvila v sodobnejše pojmovanje. Temelji Banfijevega pojmovanja so: pojmovanje umetnosti kot del sodobnega življenja, avtonomija umetnosti, razlikovanje med estetičnostjo in umetnostjo, vprašanje družbenega pomena in materialnosti $\mathrm{v}$ umetnosti, problem zgodovine umetnosti in razlik med posameznimi umetnostmi itd. Zdi pa se mi, da gre v tem bujnem bogastvu in raznolikosti idej Banfija in njegove šole poudariti predvsem eno jedro, ki ni sicer zelo vidno oz. je tako vidno in navzoče, da ga pravzaprav niti ne vidimo več: kot predmet, ki ga imamo vedno pred očmi in se nam zdi sam po sebi umeven. Temelj vsega je človek, subjekt. Brez človeka, ki čuti in zaznava ni sveta, ni umetnosti. Banfi imenuje to očitno "človeškost« humanizem in ga posebej omenja tudi v enem svojih zadnjih spisov. ${ }^{20}$ Pomen subjekta je $\mathrm{v}$ tem, da je začetek in konec interpretacijskega kroga. Tudi Rognoni in Formaggio večkrat poudarjata osrednji pomen človeka. S tem humanizmom pa so povezane še druge dimenzije, taki sta npr. komunikacijska in etična. Predvsem ta je pomembna oz. se vedno konkretneje pojavlja v Banfijevi estetiki in v estetiki njegovih učencev. ${ }^{21}$ To je razlog, zaradi katerega Rognoni v svojih poznejših muzikoloških spisih zavrača npr. Cagea in aleatoriko, v katerih je vpliv humanosti zelo omejen. O tako pomembni temi je pisal tudi Formaggio, ki je že na začetku svojega uvoda k Banfijevim estetskim spisom kot dejavnik prvega Banfijevega obdobja poudaril "umetnost v splošnem gibanju etičnega duha«. ${ }^{22}$ Formaggio ugotavlja, da se tu "že orisuje in predoči - za popolno razumevanje umetniške izkušnje - temeljna potreba po tem, kar je pozneje Banfi imenoval humanost umetnosti, tj. širšem umetniškem gibanju v družbi in zgodovini, ki bi ga morali v resnici označiti kot etično, čeprav je ob tem tudi estetično«. ${ }^{23}$

Ob vsem tem pa nam je Banfi ponudil nedogmatsko raziskovalno metodo kot verjetno najizvirnejši del njegovega filozofskega razglabljanja, ki ga je zapustil svojim učencem in prihodnjim rodovom. Banfi je sicer najbolj vplival na svoje učence predvsem v drugem obdobju svojega razmišljanja. Formaggio v obravnavi učiteljeve misli vidi v tretjem obdobju pravzaprav koherentno razvojno kontinuiteto, v kateri se je veliki preobrat estetike zgodil le delno (dokončanje v višji sintezi filozofije umetnosti je namreč predčasno ustavila smrt), „[...] do tega preobrata morda nismo do zdaj bili dovolj pozorni ${ }^{24}$ Dokaz je vrnitev Banfija in medias res:

\footnotetext{
Banfi, La mia esperienza filosofica, v La ricerca della realtá, Il Mulino, Bologna 1966; str. 1.

Zanimivo poglabljanje odnosa med Crocejevo in fenomenološko estetiko je razvil Gabriele Scaramuzza v spisu Estetica crociana ed estetica fenomenologica, $\mathrm{v}$ Crisi come rinnovamento, Milano, 2000.

20 Banfi, La mia esperienza filosofica. Tu smo pred novimi razvoji, saj je postal v povojnem času humanizem predmet številnih filozofskih debat, npr. polemika med Sartrom in Heideggrom.

21 Antonio Erbetta, Per una lettura di Antonio Banfi, v Cultura e scuola, 1976; str. 105.

22 Formaggio, Gli sviluppi dell'estetica di Antonio Banfi, v Filosofia dell'arte; str. 11.

23 Formaggio, Gli sviluppi dell'estetica di Antonio Banfi, str. 11.
} 
[...] ponovna pridobitev neuničljive umetniške funkcionalnosti postane ponovna teoretična pridobitev ene polarnosti, skrajno sodobne in uporabne za vsako in katerokoli umetniško izkušnjo, umetniško funkcionalistično - proti estetiki in proti lepoti - in ponovna socialna in kulturna (a zato ne zunaj estetska) pridobitev celotnih območij razširjene umetniškosti od vaz do kitajskih ljudskih plesov, hišne opreme, urbanistike in industrijskega oblikovanja. ${ }^{25}$

[...] Banfi v svojem tretjem obdobju poskuša izpeljati ta 'posel' do konca: od eidetske metode, tj. od ideje estetskoti, se vrne med zapletene skupine konkretne umetniške izkušnje in fenomenološko preizkuša in preizkuša pot dinamične filozofije umetnosti. ${ }^{26}$

Tu se tudi oblikuje hipoteza o vključevanju nove umetnosti v obnovljeno družbo, obenem pa se pojem umetniškosti preoblikuje tudi v plodnem stiku z zunajevropsko, $\mathrm{v}$ tem primeru s kitajsko umetnostjo. Tu se tudi pokaže izjemna sodobnost Banfijeve misli, saj se danes po 50 letih tudi zaradi množičnega izseljevanja preštevilnega naroda kitajska misel in kultura vedno bolj širita tudi v togo zaprto Evropo. Tudi Gentili, čeprav jasno piše, da se to tretje obdobje razvije brez prave kontinuitete $z$ drugim, v nadaljevanju svojega kritičnega pretresa ugotavlja, da se je Banfijeva pozornost "premaknila od čistega metodološkega območja h konkretnemu umetniškemu izkustvu, k strukturni sestavi umetniške stvaritve « ${ }^{27}$ Večina Banfijevih učencev je na poznejše zadnje obdobje učiteljevega raziskovanja gledala nekoliko odmaknjeno, ker so se v njem pojavili tudi vplivi bolj ali manj konkretnega političnega delovanja, za katerega so verjetno mislili, da ne sodi v filozofskoestetski okvir. ${ }^{28}$ Med prvo in drugo svetovno vojno so se na Banfijevih urah srečevali takrat mladi nadebudni misleci, ki so po drugi svetovni vojni usmerjali umetniško dejavnost v Italiji. Eden teh učencev, Giovanni Maria Bertin, se tako spominja svojih kolegov:

V tako živahni skupini je vsak čutil, da je vodja šole; z določenega stališča je bilo to res. V okviru skupne Banfijeve smeri je namreč vsak označil svojo izvirno pot; in od revije "Studi filosofici« - to je bila maestrova revija - so se razvile revije »Pensiero critico«, ki jo je ustanovil Cantoni, »Aut aut«, ki jo je oblikoval Paci, in »Il Verri« Anceschija; ta je bil najsamotnejši od vseh. ${ }^{29}$

V tej skupini se niso vsi posvetili razmišljanjem o umetnosti. Najprej sta to storila dva filozofa, ki sta pripravila svoji diplomski nalogi pod njegovim mentorstvom: Autonomia ed eteronomia dell'arte Luciana Anceschija in Fenomenologia della tecnica artistica Dina Formaggia; ${ }^{30}$ ob njiju pa sta še posebno zanimiva Enzo Paci in Luigi

\footnotetext{
Formaggio, Filosofi dell'arte del Novecento, str. 185.

Formaggio, Filosofi dell'arte del Novecento, str. 187.

Formaggio, Gli sviluppi dell'estetica di Antonio Banfi, str. 29.

Carlo Gentili, Lineamenti di estetica banfiana, v Nuova fenomenologia critica, Paravia, Torino 1981; str. 114-115.

Po vojni, med katero se je Banfi vključil v tajno protifašistično gibanje znotraj univerze, je bil leta 1948 izvoljen kot senator iz vrst takratne italijanske komunistične partije.

29. Che importa ci parla? ur. Michele Gullinucci, Diabasis, Reggio-Emilia, 1992; str. 27.

30 Luciano Anceschi, Autonomia ed eteronomia dell'arte, prva izdaja leta 1936, ponatis iz leta 1992 in Dino Formaggio, Fenomenologia della tecnica artistica, prva izaja je iz leta 1953, ponatis iz leta 1978).
} 
Rognoni, ki sta veliko skupno debatirala o estetiki v glasbi. Paci nam je v svojem opusu, ki je tako obsežen in toliko raznolik, da bi potreboval samostojno raziskavo, zapustil nekaj drobnih, a pomembnih spisov, v katerih izrecno piše o glasbi. Luigi Rognoni pa je eden najpomembnejših italijanskih muzikologov, z njegovim delom je Husserlova filozofija v Banfijevi preobleki "sodelovala" pri oblikovanju italijanskih muzikoloških usmeritev v drugi polovici 20. stoletja in mogoče celo pri sami muzikološki stroki v Italiji.

V svoji analizi italijanske povojne estetike iz leta 1958 je Piero Raffa posvetil Banfijevi zapuščini enega od treh poglavij. Naj najprej omenim kot zanimivost dejstvo, da Raffa omenja Banfijeva učenca tudi v glasbeni publicistiki (Rognoni, Gavazzeni), dodal pa je še D'Amica, ki je sicer sodeloval z Rognonijem, ni jih pa uvrstil v Banfijevo poglavje oz. v stik z maestrovo mislijo. To seveda pomeni, da je ta muzikološki razvoj Banfijeve smeri nekoliko v ozadju ter da je zato ta del pričujoče razprave toliko pomembnejši, ker odkriva povoje italijanske muzikologije. ${ }^{31} \mathrm{~V}$ poglavju o Banfiju Raffa ugotavlja, da je Banfi malo znan "zaradi dogodkov v zadnjih petdesetih letih zunaj določenega študijskega kroga«, ob tem pa poudarja, da »v dejanju samem, ko je kazal na široko in osupljivo obzorje izkušnje, ni nameraval zapustiti svoje 'goethejevske opazovalne točke na Olimpu' [...]; vabil je k bogastvu, ostal pa je pri čistosti; na stežaj je odprl okno in rekel: 'Glejte, koliko je svet raznolik', ni pa odšel v svet in ga pogledal od blizu«.32

Čeprav je - kot smo že omenili - Banfi v svojem zadnjem obdobju res skušal "pogledati od blizu«, je v resnici najplodnejši in najbolj znan del njegove filozofije prav to teoretično gledanje na snov. Raffovo mnenje je sicer nekoliko preveč shematično, vendar nakazuje določeno smer, stališče, iz katerega je Banfi izhajal. Še enkrat nam Rognoni ponudi zanimivo razlago:

Banfijeva filozofska estetika je pridobila določeno teoretično naravo in ni ostala zgolj preprosta metodološka usmeritev. Gotovo je, potem ko so postavljeni temelji za ustanovitev fenomenološke estetike, treba izdelati še ves tisti sistematski del, ki ga je Banfi zaslutil in nakazal v glavnih obrisih. ${ }^{33}$

Banfijevi učenci, ki so se ukvarjali z estetiko, so v resnici »šli v svet«. Za Anceschija je bil ta svet pesniški, za Formaggia figurativni, za Rognonija glasbeni. Gentili npr. piše, da je Anceschijeva raziskava "uresničevanje in samosvoje udejanjanje Banfijeve metodologije na ravni zgodovinsko kritične prakse.${ }^{34}$ Predvsem ti trije so se poglobili in medias res s tem, da so pisali o specifičnem področju in gledali nanj iz estetskega zornega kota. Ti teoretični svetovi so še vezani na učiteljev nauk, v njih se zrcalijo, udejanjajo in razvijejo maestrove ideje. Tako imajo njihove človeške in miselne poti skupno izhodišče v predvojnih kulturnih milanskih krogih, predvsem pa v obiskovanju

31 Da je ta razvoj glasbene fenomenologije še neodkrit, priča tudi novejša knjiga Augusta Mazzonija La musica nell'estetica fenomenologica (Milano, 2004). V svoji raziskavi o fenomenologiji v glasbi ni avtor niti omenil Banfija, medtem ko je podrobno predstavil razvojno vejo, ki pelje od Husserla vse do Ingardna in Zofie Lisse.

32 Piero Raffa, Situazione dell'estetica italiana, v Nuova corrente, 11-12, 1958; str. 24.

33 Rognoni, Il pensiero estetico di Banfi e la vita dell'arte, str. 54.

34 Gentili, Lineamenti di estetica banfiana, str. 130. 
Banfijevih predavanj. V povojnih letih - to so bila leta "velikega vključevanja italijanske filozofije v tok svetovne sodobne misli«35 - pa so se njihove poti razšle, Anceschi je odšel v Bologno, Formaggio v Pavio, Rognoni pa v Palermo. ${ }^{36}$

Nepričakovano se je $\mathrm{v}$ tej nalogi ob čisto estetskih pojmih pojavila še druga dimenzija, tj. zgodovinska rekonstrukcija začetkov muzikologije v Italiji. Ugotovila sem, da je Rognoni s svojim delom dejavno spodbujal sodobno glasbeno delovanje in postal eden prvih profesorjev muzikologije v Italiji, to pa pomeni, da so začetki italijanske muzikologije označeni tudi s fenomenološkimi poganjki. Iz zornega kota estetike glasbe se je zaiskrila zelo zanimiva nit, ki vodi od Luigija Rognonija in Enza Pacija k Giovanniju Piani, enemu najživahnejših in najbolj razgledanih raziskovalcev glasbenega danes.

V razglabljanju o glasbenem pa se mi zdi posebno zanimiva ideja, ki sem jo oblikovala v poglavju o Rognoniju, da je veliko sodobnih skladb oblikovanih kot sestavljenka že slišanih in priljubljenih melodičnih, ritmičnih ali harmonskih celic, delčkov: to sestavljenko sem preimenovala v "patchwork«. Ta ideja ni nikakor novost na glasbenem področju, saj se glasba od nekdaj premika med prijetno zabavo in umetniškimi dosežki. S tem mojim interpretacijskim modelom pa je možno razložiti velik del sodobne glasbene ustvarjalnosti in ga umestiti v širši sodobni glasbeni tok. Za te skladbe so značilne všečnost in uporaba, ki se skuša prebiti ven iz ozkega kroga poznavalcev: v tej svoji izbiri postane pa potrošno blago. Če naredimo še nekaj korakov po tej glasbeni poti, se mi zdi, da se tak način umetniškega ustvarjanja lahko razlaga tudi z besedami Leva Krefta:

[...] sprememba umetniškega dela v množično blago je skupaj z nastankom prostega časa in nanj vezane potrošnje odprla polje množične umetniško kulturne proizvodnje. Tu se je v dvajsetem stoletju razvila kulturna industrija (vključno z zadnjo, postindustrijsko revolucijo), ki nikakor ne pomeni samo uporabe novih tehnoloških možnosti in izumov za umetniški užitek in zabavo, ampak s svojo vsepristonostjo in množičnostjo sama naddoloča, kaj je sploh umetniško, kulturno, zabavno. Avantgardistična zahteva po sestopu in povratku umetnosti v življenje je dobila povsem nepričakovan odgovor, saj je poleg neposredne industrije kulture in zabave vidik lepe oblikovanosti in izgleda postal nujna sestavina vsakega blaga. ${ }^{37}$

Tako imajo tudi te skladbe patchworks »vidik lepe oblikovanosti«, se poslužujejo tehnoloških dosežkov in so nedvomno širše sprejemljive. Če sledimo Kreftovemu razmišljanju še naprej in na tak način nekoliko presežemo tu izbrane kronološke meje pridemo do presenetljivih in negativnih posledic, ki danes načenjajo estetiko:

\footnotetext{
Giuseppe Semerari, L'opera e il pensiero di Enzo Paci, v Rivista critica di storia della filosofia, 1977; str. 86.

36 Rognoni je na spodbudo Pacija in svojih prijateljev sodeloval na prvem natečaju (in zmagal) za mesto rednega profesorja muzikologije ("prvo, ki je bilo sploh razpisano v Italiji, kar se spominjamo«). Rognoni je bil namreč zelo v dvomu, naj se prijavi ali ne, ker ni imel akademskih naslovov.

37 Lev Kreft, Nastanek, konec in začetek estetike, str. 194.
} 
[...] avtonomije umetnosti, ki je zrasla znotraj te meje [področje etičnega užitka, op. a.], pravzaprav ni več, toda življenje, v katerega se je s tem vrnila, ni več tisto, kar si je predstavljala, ko je sama terjala estetizacijo vsakdana, pa tudi umetnost ni več tisto, kar so hoteli umetniki privesti v življenjsko prakso »nazaj«. Estetike so se ti procesi, ki so se začeli dejansko že sredi prejšnjega stoletja, resneje dotaknili šele sredi dvajsetega. Iz teh sprememb izvedene posledice za teorijo pa so postale širše sprejemljive šele po šestdesetih, torej v obdobju, ki mu rečemo "postmodernizem ${ }^{38}$

Tako kot tukaj sem se pri raziskovanju Banfijeve misli in misli njegovih učencev vedno znova znašala pred številnimi zanimivimi na stežaj odprtimi in vabljivimi vrati. V resnici pa sem želela seči predvsem začetke (pozabljenega) ključnega jedra italijanske estetike, ki je $\mathrm{v}$ tem smislu in $\mathrm{v}$ teh smernicah del splošne evropske stvarnosti, vpet vanjo tako z zgodovinskimi kot sodobnejšimi vezmi. V teh jedrih sem pravzaprav šele začela odkrivati pravi preobrat $\mathrm{v}$ razmišljanju italijanske estetike, ki se je tako popolnoma posvetila sodobnemu in ni več operirala s starimi pojmi. Odkrivala sem same izvire sodobne italijanske fenomenološke estetike in izvire tistega preobrata, sredi katerega smo še danes. To delo je pravzaprav le prvi korak na poti pojasnjevanja in poglabljanja različnih vidikov in številnih novih ugotovitev. Ob tem pa upam, da bo italijanska estetika začela ponovno odkrivati še danes žive dele Banfijeve misli in dosežkov njegove šole, ki so se v zadnjih desetletjih nekoliko porazgubili.

\section{SuMmary}

Banfi was born in the small town of Vimercate near Milan on September 30, 1886. In autumn 1909 he received his $\mathrm{PhD}$, in 1910 noted down his first thoughts on aesthetics, and composed his first rounded-off writing in 1920. After obtaining his doctorate, a scholarship enabled him to leave for Berlin, where he lived from April 28, 1910, to March 1911. Hardly a month after having settled there, Banfi wrote a short synthetic essay on the problems of aesthetics, thus commencing his fruitful research in arts which, eventually, developed into an actual school of thinking. Banfi's pupils Luciano Anceschi and Dino Formaggio have devided Banfi's aesthetic thought into three periods, the main difference between their temporal divisions being that Anceschi's interpretation takes into account Banfi's continual development, whereas Formaggio considers only the more important stages. After World War I Banfi had to work at a time of rising fascism in Italy, which, after 1925, thwarted all democratic endeavours, so that most, still living opponents of the new regime were either in prison or abroad. Unfortunately, fascist tyranny meddled also in cultural affairs, imposing its own autarkic culture, although Italian aesthetics felt the necessity of renewing its concepts contrary to idealism, or at least not under its influence, i.e. away from Croce. On one hand, Banfi accepted those concepts coming from tradition, such as e.g. the concept of the beautiful and the beaux-arts, which forced him to undertake the demanding task of confronting Croce. On the other, he developed a novel concept of art on new bases, according to which art is not a museum exhibit but rather a component part of contemporary life. Banfi's aesthetic thought developed by way of freeing himself from traditional bonds and heading for more contemporary solutions. The bases of Banfi's thinking are, as follows: the concept of art as part of contemporary life, the autonomy of art, the distinction between aestheticality and art, the question of social importance and materiality in art, the problem of art history and of the differences between individual arts etc. Within the richness and variegatedness of Banfi's ideas and his 
school the very essence should be emphasized: the basis of everything is man, the subject. Without a man, who feels and perceives, there is no world, no art. The importance of the subject lies in the fact that he/she represents the beginning and the end of the interpretational circle. This very humanism is on the other hand connected with other dimensions, such as those of communication and ethics, the latter of which is of great importance or rather assumes ever more concrete forms in Banfi's aesthetics as well as in that of his pupils.

Banfi's pupils involved in aesthetics were Luciano Anceschi, Dino Formaggio, and Luigi Rognoni. All three delved into "medias res« by writing on a certain field of interest and by observing it from an aesthetic viewpoint (Anceschi was interested in poetry, Formaggio in the figurative world, Rognoni in music). Their theoretical worlds appear to have been linked to Banfi's teaching, their writings mirroring and realizing the maestro's ideas. Their social and reflective ways had therefore a common point of departure both in the cultural circles of pre-war Milan as well as, and above all, in attending Banfi's lectures. However, after World War II their ways parted: Anceschi left for Bologna, Formaggio for Pavia, and Rognoni for Palermo.

The paper comes to the conclusion that Luigi Rognoni's efforts have stimulated contemporary musical activities, and that by his becoming one of the first professors of musicology in Italy the beginnings of Italian musicology have been characterized also by phenomenological offshoots. Looking from the viewpoint of musical aesthetics, an interesting thread has surfaced, leading from Luigi Rognoni and Enzo Paci (also Banfi's pupil and thinker whose extensive output offers a number of highly interesting writings on music) to Giovanni Piana, one of the most animated as well as learned scholars in contemporary musical studies. 